\title{
Deadly Inertia: A History of Constitutional Challenges to Canada's Criminal Code Sections on Prostitution
}

\section{John Lowman}

School of Criminology, Simon Fraser University, University Drive, Burnaby, Canada.

Email: lowman@sfu.ca

Received June $10^{\text {th }}$, 2010; revised February $18^{\text {th }}$, 2011; accepted March $24^{\text {th }}, 2011$.

\begin{abstract}
This paper examines rhetoric surrounding prostitution law reform in Canada from 1970 to the present. During the 1950s and 1960s, there was very little media or political attention paid to prostitution. It was not until the mid 1970s that perceived problems with prostitution law began to surface, driven by concerns that the criminal code statute prohibiting street prostitution was not enforceable. In 1983 the Liberal government appointed the Special Committee on Pornography and Prostitution to consider options for law and policy reform. However, the Conservative government that received the report in 1985 rejected the sweeping law changes the Special Committee recommended, opting instead to rewrite the street prostitution offence. Since then the murder of somewhere between 200 and 300 street prostitutes has prompted renewed calls for law reform. The debate on law reform culminated in 2006 with a parliamentary review that saw all four federal political parties agreeing that Canada's prostitution laws are "unacceptable," but unable to agree about how to change them. The majority report held that consenting adult prostitution should be legal, while the minority report held that it should be prohibited. In 2007 the Standing Committee on the Status of Women recommended that Canada adopt the Nordic model of demand-side prohibition. As the deadlock continues, women in the street sex trade continue to be murdered. Faced with this deadly inertia, two groups of sex workers have challenged several Criminal Code sections relating to prostitution, arguing that they violate several of their Constitutional rights, including their right to "life, liberty and security of the person". The paper concludes with an update on the progress of the Charter challenges now before the courts.
\end{abstract}

Keywords: Prostitution Law Reform, Canada

\section{Introduction}

The legal status of prostitution ${ }^{1}$ varies internationally more than almost any other kind of human activity. At one end of the spectrum are countries like the Netherlands and New Zealand where prostitution is formally lawful, including the operation of brothels and other sex-service businesses. In the center are countries like Canada and England, where the acts of buying and selling sex are legal, but brothels, procuring and living on the avails of prostitution of another person are prohibited. At the other end of the spectrum are South Africa and the United States, where selling and buying sexual services

${ }^{1}$ As the subject of this paper is prostitution law, I use the term "prostitution" and "prostitute" to distinguish exchange of physical sexual services for reward from other kinds of sex work and sex worker. are criminally prohibited ${ }^{2}$. In 1999 Sweden was the first of country to adopt the radical feminist ${ }^{3}$ or "Nordic ${ }^{4}$ ", version of prohibition, which involves criminalizing sex buying and third-party facilitation of prostitution. In this legal regime the sale of sex continues to be lawful on the grounds that because prostitutes are victims of male exploitation and violence against women they should not be punished. From this perspective, prostitution is violence against women.

\footnotetext{
${ }^{2}$ One exception in the US is the State of Nevada, which allows sex businesses to operate in eleven out of 17 rural counties.

${ }^{3}$ It is open to debate whether the demand-side prohibition advocated by self-identified radical feminists like Ekberg [1], one of the main architects of current Swedish prostitution law, is an essential feature of radical feminism in general, or the position of a constituency within radical feminism.

${ }^{4}$ Norway and Iceland followed suit in 2009.
} 
As Canada considers its options for prostitution law reform, many of the arguments favouring prohibition have been put on trial as a result of a series of challenges to the constitutional validity of its prostitution laws. In the wake of more than 200 known murders or manslaughters of sex workers over the past twenty-five years with many more street-connected women reported missing, two groups of current and former prostitutes are seeking declaratory relief in relation to various prostitution laws which, they allege, violate their constitutional rights, including their right to life, liberty and security of the person (Downtown Eastside Sex Workers United Against Violence Society and Sheryl Kiselbach v. Canada, 20085 ; Bedford v. Canada, 20106). If they are successful and the laws are struck down-a process that will take several years as the cases head towards the Supreme Court of Canada - it is likely that the Canadian federal government will be forced to either criminalize prostitution, or alter the criminal law to allow regulation at the provincial and municipal level, as mere tinkering with the wording of the impugned provisions would not appear to be capable of solving the constitutional objections.

This article describes the debate over prostitution law reform that culminated in 2006 with a parliamentary review that saw all four federal political parties agreeing that Canada's prostitution laws are "unacceptable”, but unable to agree about how to change them [2]. The fundamental controversy over prostitution law reform that has led to this deadly inertia exemplifies the clash between "radical" and "liberal" feminists ${ }^{7}$ that has been replayed around the world in numerous settings over the past twenty-five years, except that in this instance Canadian courts are evaluating the evidence presented for and against prohibition. The essay concludes with an update on the progress of the two main Charter challenges currently before the courts.

\section{The Development of Canadian Prostitution Law}

Canada's first prostitution laws were imported with British common law. They dealt with the nuisances attributed to bawdy houses and street walking, which they treated as forms of vagrancy and immoral $[4,5]$. At the time of Confederation, because law treated women and children as the property of men it offered them little protection from men. In the latter part of the nineteenth century attitudes on both sides of the Atlantic began to change

\footnotetext{
${ }^{5}$ Full case citations are listed after the references.

${ }^{6}$ In a third case, R. v. Blais (2011), a client charged with communicating in public for the purpose of buying sex defended himself by arguing that the "communicating law" infringes the constitutional rights of prostitutes. The court rejected his argument.
}

during a period when women came to be seen as moral guardians of the family deserving protection from licentious men. The unfolding "social purity" crusade portrayed prostitution as a "social evil" involving a "white slave trade".

As the social purity movement gathered momentum it achieved alcohol prohibition in some Canadian jurisdictions and, in the name of preventing exploitation of women and children, successfully lobbied for a series of criminal laws prohibiting procuring, living on the avails of prostitution of another person, and expansion of the bawdy house laws.

With the exception of the vagrancy statute (described below) that, up until 1972, was used to control street prostitution, the laws in place by 1915 remain in effect today:

- Procuring a person to have illicit sexual intercourse; aiding, abetting or controlling for gain the prostitution of another person; enticing a person who is not a prostitute to a common bawdy house or concealing a person in a common bawdy house (s.212.(1)). These are indictable offences subject to sentences of up to ten years imprisonment.

- Living in whole or in part on the avails of the prostitution of another person (s.212.(1)(j)), an indictable offence subject to a sentence of up to ten years in prison.

- Owning, keeping, frequenting, being a landlord of, or being found in a "common bawdy house," i.e. any "place" that is used on a regular basis to conduct commercial sexual transactions (s.210). "Keeping” is an indictable offence carrying up to two years imprisonment, the others are summary offences, and thus subject to the maximum penalty for any summary offence, i.e. not more than two thousand dollars

\footnotetext{
${ }^{7}$ The radical feminist — or what Jolin [3] calls the "sexual equality first" perspective - on prostitution holds that, because male power is inextricably linked to female subjugation, equality for women depends directly on the elimination of male sexual oppression. Advocates of this position argue that, because prostitution is predicated on sexual subordination of women, abolition of prostitution is a prerequisite to securing women's rights. Against this view, liberal feminists and other advocates of what Jolin [3] calls the "free choice first" perspective argue that freedom to choose is a prerequisite of women's equality. "For feminists of this persuasion, the fight for women's equality depends on the rejection of all attempts by men or women to forcibly impose their will on women... if freely chosen, prostitution is an expression of women's equal status, not a symptom of women's subjugation” [3]. The two positions differ fundamentally in the way they conceptualize "choice". Advocates of demand-side prohibition argue that no woman who has a free choice would choose to prostitute. Advocates of the libertarian model argue that, because people have to make choices in social and economic circumstances that they do not choose, social and legal policy should be designed to maximize choice, not limit it. Prohibition of the buying or selling of sexual services creates adverse effects that disproportionately affect women who sell sex, whether it be for the better pay it provides compared to other service industries or when no other economic alternatives are available.
} 
or to imprisonment for six months or both (Criminal Code s.787.(1)).

- Transporting a person to a bawdy house (s.211), a summary offence.

- As of 1985, the communicating law prohibits any form of communication in a public place or place open to public view for the purpose of buying or selling sexual services (s.213), a summary offence.

In 1988 in response to recommendations of the Committee on Sexual Offences Against Children and Youth [6] and the Special Committee on Pornography and Prostitution [7], two new statutes relating to youth involvement in prostitution were enacted: 1) a separate offence with a fourteen year maximum prison sentence for living on the avails of a person under eighteen years of age (s.212.(2)); and 2) prohibition of buying or offering to buy sexual services from a person under eighteen with a prison sentence of no more than five years (s.212.(4)).

In 1997 following recommendations of the FederalProvincial-Territorial Working Group on Prostitution [8], the legislature amended the Criminal Code by adding s.212.(2.1), which created a five year minimum prison term for "aggravated" living on the avails of a person under eighteen, and s. 7(4.1) which allows prosecution of citizens and permanent residents of Canada for committing sexual offences against children outside of Canada, including sexual interference, sexual exploitation, making, distributing or selling child pornography, and attempting to obtain or obtaining for consideration a sexual service from a person under eighteen years of age. At least thirty other countries have similar "sex tourism" prohibitions.

In August 2010 using the powers bestowed by Code s. 467.11(4), which authorizes the government to respond to organized crime via an Order-in-Council rather than a legislative change, the minority Conservative government expanded the definition of "serious crime" to include ten gambling and drug offences, and the offence of keeping a common bawdy house. This change of regulations had the effect of expanding the maximum prison sentence for keeping a common bawdy-house from two to five years.

New legislation prohibiting "trafficking in persons" also applies to various prostitution-related activities; indeed because some commentators, such as the Standing Committee on the Status of Women [9], define all forms of prostitution as "exploitation”, they regard all prostitutes as victims of "trafficking”.

\footnotetext{
${ }^{8}$ The IRPA defines trafficking in persons as "knowingly organiz[ing] the coming into Canada of one or more persons by means of abduction, fraud, deception or use or threat of force or coercion." No convictions have ever been recorded under this provision (International Centre for Criminal Law Reform and Criminal Justice, 2010, p.4).
}

In 2002 Section 118 was added to the Immigration and Refugee Protection Act to prohibit human trafficking into Canada, with a maximum penalty of life imprisonment and/or a fine of up to one million dollars ${ }^{8}$. In 2005 four sections were added to the Criminal Code to prohibit domestic human trafficking ${ }^{9}$.

The rationale for changes to street prostitution lawsfirst in 1972 and again in 1985-is described below along with the events that precipitated Canada's “street prostitution problem" in the late 1970s and early 1980s. A short description of prostitution law enforcement and styles of prostitution through the Twentieth Century sets the stage for this account.

\section{The Role of Law Enforcement in Shaping the Practice of Prostitution}

Across North America in the latter part of the nineteenth century, enforcement of prostitution laws has been described as "sporadic and capricious" [5]. Many cities contained a "segregated" or "restricted" district where prostitution was tolerated (see e.g. $[10,11]$ ), often because police took bribes to ignore it.

At the turn of the century, social purity reformers pressed police to abandon the prevailing regime of toleration in favour of vigorous law enforcement against procurers and persons living on the avails of prostitution. However, efforts to suppress prostitution usually only displaced it [11], and law enforcement continued to be erratic. Police sometimes targeted prostitutes rather than "exploiters" to boost the number of charges to make it look like they were serious about fighting the "social evil" [5]. Brothel prostitution appears to have survived the vice crusades of the first twenty years of the twentieth century, and flourished up to the Second World War. After 1920 the social purity discourse waned, only to be replaced by concerns about "social hygiene” and eugenics [12].

After World War II the 1900-1940 style of brothel prostitution that Gray [10], Nilsen [11] and Rotenberg

\footnotetext{
${ }^{9}$ Section 279.01(1) prohibits recruiting, transporting, transferring, receiving, holding, concealing or harbouring a person, or exercising control or influence over the movements of a person, for the purposes of exploiting them or facilitating their exploitation. The maximum penalty is life in prison where the offence involves the kidnapping, aggravated assault or aggravated sexual assault or death of the victim and 14 years in any other case. Section 279.02 prohibits the receipt of a financial or other material benefit for doing any of the aforementioned acts. The maximum penalty is ten years. Section 279.03 prohibits withholding or destroying travel or identity documents in order to facilitate any of the aforementioned acts. The maximum penalty is five years. Section 279.04 (a) defines exploitation, for the purpose of the trafficking in persons offences, as causing a person "to provide, or offer to provide, labour or a service by engaging in conduct that, in all the circumstances could reasonably be expected to cause the other person to believe that their safety or the safety of a person known to them would be threatened if they failed to provide, or offer to provide, the labour or service.” These are indictable offences.
} 
[13] describe apparently disappeared from some Canadian cities. Certainly the number of bawdyhouse charges dropped dramatically in the 1950s and 1960s across Canada, although this may reflect a change in enforcement priorities rather than prostitution styles. Vancouver newspaper articles from this period indicate that many female sex workers met their clients in hotels and nightclubs [14], a view that Layton's [15] study of prostitution in Vancouver substantiates. Her study also suggests that street prostitution was restricted to commercial streets in the more salubrious areas of the Downtown core and Downtown Eastside. Prus and Irini's [16] study of prostitution in Toronto describes a hotel trade facilitated by bell hops, desk clerks and taxi drivers, while Brock [17] describes extensive prostitution in body rubs and massage parlours on Yonge Street up to 1977 when they were closed (see footnote 13). Until the late 1970s the street trade in both Vancouver and Toronto appears to have been relatively limited and contained, and rarely made newspaper headlines.

While it is difficult to ascertain how extensive the prostitution trade was in the 25 years immediately after World War II, it was rarely a matter of concern in newspapers. In contrast to the period of the social purity movement from 1903 to 1917, when newspapers frequently discussed prostitution, in the 1950s and 1960s they rarely mentioned it $^{10}$. In Vancouver-the city where dozens of street prostitutes have been murdered over the past two decades-street prostitution up to 1970 was restricted to a few blocks on the Downtown Eastside. Newspaper reports suggest that a prostitution stroll had developed in Vancouver's West End by 1972, but it was the 1975 police action against two cabaret clubs where prostitutes met their customers that played the biggest part in expanding the street trade in Vancouver [18].

\section{Canada's “Street Prostitution Problem”}

Up to July 1972 street prostitution was defined as vagrancy, a summary offence. Criminal Code s.175.(1)(c) read: "Every one commits a vagrancy who... being a common prostitute or nightwalker is found in a public place and does not, when required, give a good account of herself."

Vagrancy C was repealed because it applied only to women, and thus contravened the 1960 Canadian Bill of Rights, and criminalized a woman's status as a "common prostitute" rather than her behaviour. It was replaced by the "soliciting law", which read: "Every person who solicits a person in a public place for the purpose of prosti-

\footnotetext{
${ }^{10}$ The evidence for this observation comes from an on-going study of twentieth century newspaper reports about prostitution from two newspapers: the Globe and Mail, Canada's longest-operating national newspaper, and the Vancouver Sun.
}

tution is guilty of an offence punishable on summary conviction" (Criminal Code s.195.1).

Soon after police began to enforce the new law, courts were asked to determine the exact meaning of the term "solicit". Did the mere offer of a sexual service and a price constitute "soliciting", or did it entail something more?

In 1978 the Supreme Court of Canada ruled that soliciting entailed "pressing and persistent" or "importuning" conduct (R. v. Hutt, 1978), which meant that merely offering a sexual service for a price was not sufficient to constitute an offence. This interpretation meant that the usual enforcement tactic involving an undercover officer approaching a street prostitute and arresting her once she agreed to perform a sexual service for a price no longer constituted sufficient evidence for a conviction, at which point Vancouver police stopped enforcing the law. Police in Toronto continued to obtain convictions by arguing that a sex worker approaching a series of customers in different encounters constituted "pressing and persistent" conduct, but when citizen's groups pressured Vancouver police to use the same tactic, one of the first cases to go to court was dismissed on the grounds that the serial approaches to different clients were just that: different incidents. When the Supreme Court of Canada subsequently upheld this decision (R. v. Whitter, 1981) Toronto police also stopped enforcing the soliciting law. Many commentators-including the Canadian Association of Chiefs of Police chaired by Vancouver Police Chief Don Winterton [19] and a Maclean's ${ }^{11}$ editorial [20]—blamed jurisprudence for turning Canadian streets into "sexual supermarkets".

\section{The Standing Committee on Justice and Legal Affairs ${ }^{12}$ [21]}

The first government initiative to address the expansion of street prostitution in cities like Vancouver [18] and Toronto [17] was an instruction to the House of Commons Standing Committee on Justice and Legal Affairs to review legal methods for dealing with street prostitution, including the Criminal Code and various provincial and municipal laws in force at this time, and consider the views of interested persons and organizations.

After hearing the views of federal and municipal government officials, police officers and different activist groups representing women and communities, the Standing Committee produced a short report (1983) dealing solely with street prostitution that made five recommendations:

\footnotetext{
${ }^{11}$ Canada's most widely circulated national news periodical.

${ }^{12} \mathrm{~A}$ standing committee comprises representatives of each political party in the federal government roughly in proportion to the number of seats they hold.
} 
1) That, whatever changes are made to s.195.1 of the Criminal Code, it should be amended to remove the uncertainty as to whether clients are liable to prosecution;

2) That a new offence be added consisting of the offering or the acceptance of an offer to engage in prostitution in a public place, punishable on summary conviction by a fine of up to $\$ 500$, or 15 days' imprisonment in default of payment;

3) That the definition of "public place" be amended to include vehicles in public places, and private places open to public view;

4) That a new offence of offering or accepting an offer to engage in prostitution with a person under 18 be enacted, punishable either on summary conviction or by way of indictment;

5) That the operation of the proposed amendments be reviewed by a committee of the House of Commons within three years of their coming into force (cited in [7, pp. 467-469]).

Faced with growing pressure from municipal and provincial governments for revisions to the Criminal Code, instead of acting on any of the Standing Committee's recommendations, the 1983 Liberal government appointed the Special Committee on Pornography and Prostitution (the Fraser Committee [7]) to study the sex trade in Canada and recommend law and policy reforms across the board.

\section{The Special Committee on Pornography and Prostitution [7]}

Charged with the task of ascertaining what had gone wrong with prostitution law, the Fraser Committee demonstrated that street prostitution had spread prior to the 1978 Supreme Court of Canada ruling that defined "soliciting" as pressing and persistent or importuning conduct ( $R$ v. Hutt, 1978). Neither the Maclean's editorial nor Police Chief Winterton when he wrote about the "dilemma of our prostitution laws" [19] mentioned that it was the Vancouver Police who had contributed to the expansion of street prostitution by closing off-street prostitution locations.

In 1975 Vancouver police turned their attention from street prostitution to the indoor trade. While the reasons for this change of emphasis are not clear-it does not appear to have been driven by public complaints or lobby group pressure-we do know that the VPD vice unit conducted lengthy undercover investigations into the two cabaret clubs that provided an off-street mechanism for sex workers and clients to meet $[15,18]$. When the own-

\footnotetext{
${ }^{13}$ Brock describes the way that Toronto police and local authorities used the murder of a 14 year-old shoe shine boy, whose body was found on the roof of a body rub parlour, to justify closing Yonge Street's parlours.
}

ers and several employees of one of the clubs were charged with living on the avails, the club closed. After the other club mysteriously burned to the ground, the owner was charged with arson, but never convicted. No longer able to meet clients indoors, the women turned to the streets [18]. In Toronto in 1977 a similar displacement occurred when police closed the body rub parlours on the Yonge Street strip ${ }^{13}$ [17]. Rather than soliciting law jurisprudence being the decisive factor leading to the expansion of street prostitution, it was the interplay of a set of contradictory and self-defeating prostitution laws that played the central role-although it was obvious too that the soliciting law had failed to contain prostitution once it was displaced onto the street.

In making recommendations for law reform, the Fraser Committee urged the legislature to clarify the legal status of prostitution: if it is to continue to be lawful, where should it be located? The Fraser Committee advised against piecemeal law reform, saying that the entire set of prostitution laws needed to be rethought. The most effective way to prevent public nuisance and recognize the rights of prostitutes would be for the legislature to decide where and under what circumstances prostitution can occur.

Arguing that consenting adult sexual activity should not be subject to criminal penalty, the Committee recommended law reforms that would allow two prostitutes to work from a residence ${ }^{14}$, would permit the provinces to license small scale brothels, and would prohibit procuring and living on the avails only when threats or violence were brought to bear. Its recommended street prostitution offence would criminalize sex workers and clients only if they created specified nuisances, such as blocking doorways or stopping pedestrian or vehicular traffic.

The Committee recognized that law reform by itself could do little to address many of the problems associated with prostitution. It called for all levels of government to work together to remove the economic and social inequalities between men and women that lead to prostitution, ensure that there are adequate social programs for marginalized women and youth, and develop programs for people who want to exit prostitution.

\section{The Legislative Response}

Before the Fraser Committee released its report in April 1985 the Liberal Party that had created it lost a general election to the Progressive Conservatives. The new Conservative government ignored the Fraser Committee's

\footnotetext{
${ }^{14}$ The Committee suggested two persons to enhance their safety, but limited the number to prevent the potential nuisance that could be created by what are now referred to as "micro-brothels" in residential areas.
} 
proposal for sweeping law reform, opting instead to restrict its attention to the street prostitution law. By taking this approach it implicitly accepted the argument that jurisprudence really was the problem that led to expansion of street prostitution in the mid-1970s; if the wording of the law was the problem, then making the law easier to enforce would turn the clock back to the days when the vagrancy law supposedly ${ }^{15}$ held the street trade in check.

On December $20^{\text {th }} 1985$ the "soliciting law" was repealed and the "communicating law" (Criminal Code s.195.1, renumbered as s.213 in 1989) enacted. For the first time, the prostitute's client was explicitly made a party to the street prostitution offence, which prohibited any manner of communication in public for the purpose of engaging in prostitution or of obtaining the sexual services of a prostitute. Like the soliciting law before it, the communicating law is a summary offence ${ }^{16}$, and thus subject to a fine of no more than two thousand dollars, up to six months in prison, or both.

Police across Canada were quick to take up enforcement of the communicating law. From 1982 to the end of 1985 under the soliciting law, police across Canada laid less than an average of 100 charges each year. In contrast, during the first eight years of communicating law enforcement (1986-1993) from eight to ten thousand charges were laid each year nationwide. From 1997 to 2005 the figure dropped to between three and six thousand charges annually.

\section{Justice Canada Evaluates the Communicating Law (1989)}

The legislation introducing the communicating law required that an evaluation be conducted within four years of its enactment. To this end the Department of Justice Canada commissioned five regional studies of its impact [22-26], which are summarized in its Synthesis Report [27].

While the communicating law clarified the government's intention to use criminal sanctions to suppress street prostitution, it did nothing to clarify where the legislature would have the still-legal act of prostitution take place. It was still unclear whether Canadian prostitution law as a whole is designed to eradicate or regulate the sex trade. Justice Canada commented on the problem this created for the evaluation:

It is difficult to know whether the legislators hoped that the [communicating law] would reduce the incidence of prostitution by:

\footnotetext{
${ }^{15}$ I say "supposedly" because there are reasons to doubt whether Vag. C kept levels of street prostitution in check from 1945 to the mid 1970ssee [22].

${ }^{16} \mathrm{~A}$ summary offence is roughly the equivalent of a misdemeanour in the US, and an indictable offence the equivalent of a felony.
}

a) Convincing prostitutes and customers to give up the practice entirely;

b) By encouraging them to work in less offensive modes, such as escort services or bars, or in areas where their activity would annoy no one [27, pp. 7-8].

Regardless of which of these outcomes was intended, Justice Canada's evaluation was unequivocal in its conclusion that:

In the two Canadian cities in which street prostitution presented the greatest problem, Vancouver and Toronto, the legislation has had virtually no success in moving prostitutes off the street. Both street counts and interviews with key respondents in these cities suggest that, at best, prostitutes have simply been displaced to new areas. Street prostitutes in both cities stated that the law was not a deterrent [27, p. 74].

Similarly, the law did not reduce street prostitution in Winnipeg, Regina and Calgary.

In Montreal, Quebec City, Niagara Falls, Ottawa and Halifax numbers appeared to diminish, but according to the Synthesis Report these all were cities where street prostitution was much less of a problem to begin with.

\section{A Two-Tier System of Prostitution Law}

In contrast to the thousands of charges for communicating since 1986, there were only a few hundred charges each year for bawdy-house, living on the avails and procuring violations even though the majority of these are indictable offences. Since 1986, street prostitutionwhich is estimated to comprise between $5 \%$ and $20 \%$ of the commercial sex trade in Canada [2, p. 6] —has accounted for $93 \%$ of all prostitution law offences. To keep prostitution out of mind and sight a two-tier system of prostitution has emerged in which street prostitution is criminalized while indoor prostitution is regulated [28].

Police explain this discrimination as emanating from the complaint driven nature of prostitution law enforcement; they concentrate on the street trade because it generates the vast majority of complaints. This implies that the much bigger off-street sex trade flourishes in our midst without creating a nuisance, and police and prosecutors in cities like Vancouver are only too well aware of the problems they can create when they close down the off-street trade, as they did in the mid-1970 $\mathrm{s}^{17}$.

While this law enforcement double standard represents a pragmatic resolution to the self-defeating and contradictory nature of Canadian prostitution law, it also highlights its hypocrisy. We thus now find ourselves in a situation where there are a dozen or so "john schools ${ }^{18,}$

\footnotetext{
${ }^{17}$ In 1987 a Vancouver regional Crown counsel confirmed that one of the reasons that his office was reluctant to lay charges against escort services was because of a concern that such an action would displace the escort trade onto the street.

18“John school” is the colloquial term given to diversion programs for men charged under the communicating law.
} 
across Canada morally denouncing prostitution even though purchasing sex is not a criminal offence. At the same time many of the municipalities that sponsor john schools also license escort services and body rub parlour prostitution using licensing language which makes it clear that they are knowingly regulating prostitution [28, pp. 11-14]. Needless to say, the speakers at john school do not inform their conscript clientele that if the men had patronized a municipally licensed prostitution business such as an escort service they could have purchased sex with impunity ${ }^{19}$.

\section{Prohibition or Regulation? Dissensus on the Supreme Court (1990)}

While jurisprudence has clarified the intention and scope of each prostitution statute, not even the justices on the Supreme Court of Canada can agree what the legislation as a whole is trying to achieve. In 1990 after a series of conflicting decisions at the provincial court level, the Province of Manitoba petitioned the Supreme Court of Canada to rule on the constitutional validity of the bawdy house and communicating laws (Reference re ss.193 and 195.1(1)(c), 1990).

In a four to three decision upholding the laws, the Supreme Court justices were unable to agree about the purpose of prostitution law as a whole. Justice Lamer was the only one of seven to argue that the legislation aims to abolish prostitution:

[T]hese laws indicate that while on the face of the legislation the act of prostitution is not illegal, our legislators are indeed aiming at eradicating the practice. This rather odd situation wherein almost everything related to prostitution has been criminalized save for the act itself gives one reason to ponder why Parliament has not taken the logical step of criminalizing the act of prostitution...; [O]ne possible answer is that, as a carryover of the Victorian Age, if the act itself had been made criminal, the gentleman customer of a prostitute would have been also guilty as a party to the offence. That situation has now been rectified in that the [communicating law] reaches out to the customers of prostitutes, although the act itself is still not illegal.

Against this view, Justice Wilson (with Justice L' Heureux-Dubé concurring) reasoned:

While... many people find the idea of exchanging sex for money offensive and immoral... many types of conduct which are subject to widespread disapproval and allegations of immorality have not been criminalized.

\footnotetext{
${ }^{19}$ Although in some circumstances a client could potentially be charged for being found in a common bawdy house, I have not found an instance in Vancouver of such a charge being laid during the period I have conducted prostitution research in that city (1977-present). There appear to be very few, if any, such charges anywhere in Canada during this period.
}

Indeed, one can think of a number of reasons why selling sex has not been made a criminal offence... Whatever the reasons may be, the persistent resistance to outright criminalization of the act of prostitution cannot be treated as inconsequential... We cannot treat as a crime that which the legislature has deliberately refrained from making a crime.

Similarly, Chief Justice Dickson (with Justice LaForest and Justice Sopinka concurring) rejected Lamer's view:

Like Wilson J., I would characterize the legislative objective of [the communicating law] in the following manner: the provision is meant to address solicitation in public places and, to that end, seeks to eradicate the various forms of social nuisance arising from the public display of the sale of sex... [I]n my view, the legislation is aimed at taking solicitation for the purposes of prostitution off the streets and out of public view.

Regardless of what might have motivated Victorian legislators, none of this judicial commentary-Justice Lamer's in particular-acknowledges that, when the Fraser Committee recommended sweeping law reform in 1985, everything was up for grabs. The Conservative government of the day could have introduced legislation criminalizing the buying and/or selling of sexual services-options the Special Committee on Pornography and Prostitution discussed [7, pp. 515-517, 520-521] $]^{20}$ but chose not to.

While I return to the substance of the Supreme Court's constitutional arguments later in the paper, it is sufficient to note at this juncture that Canadian prostitution law is beset with a fundamental problem: if the justices on the Supreme Court of Canada cannot agree about the overall purpose of prostitution law, how is the average citizen supposed to figure it out? In this sense, Canadian prostitution law as a whole is vague. If it is "impermissibly vague", then presumably it offends the principles of fundamental justice that lie at the heart of the Charter. Alternatively, if the purpose of the legislation is regulation, the question remains, where should the lawful act of prostitution take place?

\section{Parliament Reviews the Communicating Law (1990)}

At the same time the Supreme Court was considering the constitutional status of communicating and bawdy house statutes, the Standing Committee on Justice and the So-

\footnotetext{
${ }^{20}$ As well as criminalization of both buying and selling sexual services, the Special Committee on Pornography and Prostitution discussed the demand-side model of prohibition that was adopted in Sweden some fifteen years later-criminalizing sex buying and other kinds of "exploitation," but not sex selling, which would continue to be legal-and found it wanting because, "This approach depends on acceptance of the thesis that prostitutes really have no desire to engage in this sort of life, and that, even if they do, they should be protected from their own rash choices" (p. 521).
} 
licitor General completed its review of the communicating law (1990). After a review of the research carried out by the Department of Justice and a series of hearings with invited speakers, the Standing Committee [29] made three recommendations.

1) That government departments develop start-up programs and core funding to community-based agencies providing programs accessible and responsive to the needs of sex workers wishing to leave the industry;

2) That the Identification of Criminals Act be amended to allow for the fingerprinting and photographing of those charged under Section 213, whether as prostitutes or as clients;

3) That Section 213 be amended to provide judges with the discretion, in addition to any other penalty imposed, to prohibit persons convicted of communicating for the purposes of prostitution in instances involving a motor vehicle from driving a motor vehicle for up to 3 months.

Parliament accepted the first recommendation on principle, but rejected the other two $[28,31] .{ }^{21}$ The status quo prevailed.

\section{Justice Canada Sponsors Research on Violence against Sex Workers (1995)}

In the five years following the parliamentary review Justice Canada contracted a series of updates of its 1989 evaluation to track the impact of the communicating law. On-going research in Vancouver through this period produced evidence that violence against street prostitutes was increasing. In 1991 for the first time the Canadian Center for Justice Statistics began publishing information about the occupation of homicide victims. These data revealed that in 1991 and 1992 twenty-two sex workers, the vast majority of whom appeared to be street prostitutes, were victims of homicide in the course of their work.

In 1993 Justice Canada sponsored a series of studies of violence against sex workers in order to examine what appeared to be escalating levels of violence [30-33]. Lowman and Fraser's study [33] revealed that the number of homicides of sex workers in British Columbia appeared to have accelerated after 1980. Of the fifty sex-worker homicides they describe during the period 1964 to 1993, only seven occurred prior to 1983 . But worse was yet to come.

\footnotetext{
${ }^{21}$ The second recommendation was rejected as not striking an appropriate balance between societal concerns about prostitutes and the law enforcement objective of suppressing street prostitution. The third recommendation was rejected because it would: a) interfere with the sentencing discretion left to judges; and b) there was no rational connection between the offence and the punishment, as street prostitution does not require use of a motor vehicle.
}

\section{The Federal-Provincial-Territorial Working Group on Prostitution (1998)}

Absent clarification of the purpose of Criminal Code statutes relating to prostitution and with murders of prostitutes, sexual exploitation of youth, and the nuisances associated with street prostitution all making news headlines [34], the federal, provincial and territorial deputy ministers responsible for justice established the Federal Provincial Territorial Working Group (Working Group) in 1992. The Working Group was asked to review the adequacy of legislation at the federal and provincial levels, the role of municipalities in prostitution policy, law enforcement issues, and make yet more recommendations for law and policy reform.

Unlike the Fraser Committee, which comprised specialists from outside government, the Working Group consisted of provincial, territorial and federal government employees whose recommendations for prostitution law and policy reform had to be acceptable to the political party that employed them, thus making independent recommendations impossible.

In an Interim Report the Working Group [35] developed a series of preliminary recommendations, some of which the Federal Government acted on in the form of Bill C-27, an Act to amend the Criminal Code in relation to child prostitution, child sex tourism, criminal harassment and genital mutilation. These amendments came into force in May 1997.

After six years of extensive nation-wide consultation and deliberation the Working Group released its final report in 1998 [8]. The report focused on the two issues that had the highest public profile at the time: youth involved in prostitution and the harms associated with street prostitution, including public nuisance and violence against prostitutes.

The Working Group produced sixteen recommendations regarding youth prostitution, and twenty concerning street prostitution, with a passing reference to bawdy house laws [8. pp. 72-77]. The members had little trouble recommending social interventions and provision of accessible services, including substance abuse programming and safe houses, but when it came to more fundamental questions about the legal status of prostitution, there was no consensus. While the Working Group recommended against decriminalizing street prostitution, it expressed concern about the way "the law is silent on when and under what conditions prostitution is allowed to occur" [8, p. 4], and suggested that the legislature might consider changing bawdy house laws to allow indoor prostitution in relative safety and help prevent nuisance in the process:

[I]nterested municipal and provincial governments 
[should] undertake discussions with each other and with the federal government regarding the option of giving municipalities more regulatory authority in relation to bawdy-houses in order to address the problems posed by street prostitution, particularly the hazards posed to residents, the involvement of youth in prostitution and the dangers to prostitutes themselves. In particular, consideration could be given to the reform of s.210 of the Criminal Code to allow one or two prostitutes operating out of their own residence where municipalities believed that the hazards and dangers of street prostitution warranted such measures. [8, pp. 69-70].

The Working Group suggested that partial decriminalization of indoor prostitution could be achieved by a law emulating s.207 of the Criminal Code, which permits provincial governments, charitable organizations and other parties to license and/or hold lotteries by exempting them from the criminal prohibition of gambling set out in other sections of the Code.

Again the legislature did nothing to resolve the fundamental issue first raised by the Fraser Committee thirteen years before: if prostitution is legal, where and under what circumstances should it occur? It was at about this same time that pressure from local social services agencies, prostitute's rights organizations and local journalists began to mount for the Vancouver Police Department (VPD) to make a more concerted effort to investigate the disappearance of dozens of street-involved women from the Downtown Eastside just a few blocks from police headquarters.

The Downtown Eastside comprises one of the ten poorest census tracts in Canada [36], has some of the highest HIV and Hepatitis C infection rates in the Western world ${ }^{22}$ is the location of Canada's first needle exchange program and, through a process of urban triage, has become home to a substantial population of persons diagnosed as mentally ill. The area contains 5000 single room occupancy accommodation, which constitutes about $80 \%$ of the Vancouver total, 5000 social housing units, and 900 special needs housing beds. Of roughly 16,000 residents, 700 are homeless.

In 1991 Vancouver Police Department identified over 450 women involved in the Downtown Eastside street prostitution trade at one time or another that year, many of whom were aboriginal. It was this population of women that became the primary target of serial killer Robert Pickton.

\footnotetext{
${ }^{22}$ Leidl [37] estimates the DES population's HIV infection rate to be about $30 \%$ and the HCV rate to be just below $70 \%$-roughly the equivalent of Botswana.

${ }^{23}$ When asked in 1999 to put up a reward for finding a missing woman, Mayor Owen was reported as saying that the authorities were not prepared to fund a "location service" for prostitutes [38].
}

\section{Robert Pickton and Vancouver's Missing Women}

From 1995 through 2001, 46 women who were known to have worked in the Downtown Eastside prostitution stroll were reported missing. After several years of denial by the police and the municipal council that a serious problem existed ${ }^{23}$ a joint RCMP-VPD Missing Women Task Force was established in 2001.

On February $5^{\text {th }} 2002$ when police exercised a search warrant for illegal firearms at Robert Pickton's farm they discovered human body parts. On February $22^{\text {nd }}$ Pickton was arrested and charged with two murders. The subsequent twenty-month long inch-by-inch search of the farm, which involved hand screening the topsoil of the entire 16 acre property looking for evidence, is estimated to have cost over one hundred million dollars. The search produced the DNA of 33 women who had been reported missing from the Downtown Eastside between. When Pickton initially went to trial he was charged with 26 murders. However, twenty charges were severed with the intention of processing them at a separate second trial to be held after the first one was concluded.

On December $9^{\text {th }} 2007$ Pickton was convicted of all six murders. After the Supreme Court of Canada upheld these convictions, the Crown stayed the remaining twenty charges, arguing that it would be too costly to proceed given that Pickton will never be released from prison.

\section{Grandma's House}

The case of Grandma's House, a charitable society established in 1998 by Jamie Lee Hamilton ${ }^{24}$ to help survival sex workers in the Downtown Eastside/Strathcona, epitomizes the issues that are being raised by the constitutional challenges to prostitution law currently before the courts.

At about the same time Grandma's House opened in 1998, fear that a serial killer was preying on the area's sex workers was rife on the street, and the Vancouver media were beginning to report the disappearance of numerous street-connected women. We now know that 10 women disappeared from this area in 1997, nine in 1998, and 6 in $1999 .{ }^{25}$ Hamilton has reported that women would sometimes arrive at Grandma's House bloodied and bruised after a bad date. Some of them asked Hamilton if they could bring dates to Grandma's House so that they could conduct their business safely: with other people around, they would be able to get help if a date turned bad. During this period Hamilton publicly criticized Vancouver Police Department on numerous occasions

\footnotetext{
${ }^{24}$ This account is based on my personal communications with Ms. Hamilton, a Vancouver prostitute rights activist.

${ }^{25}$ These figures were compiled by then Detective Inspector Kim Rossmo of the Vancouver Police Department.
} 
for failing to investigate the disappearance of dozens of women, and did not attempt to hide what was happening at the House. It may well have been this activism that led to VPD charging her in 2000 with keeping a common bawdy house. ${ }^{26}$

In the ensuing trial Hamilton challenged the constitutional validity of the law. The general gist of her argument was that if a bawdy house is not located in a residential area, it is unlikely to be a nuisance. Because no profit was involved-the charge for the room was sufficient only to cover costs for rent, bedding, towels, etc.Grandma's House did not exploit the sex worker's labour. Indeed, its purpose was to protect sex workers from murder while avoiding the creation of a public nuisance in the process. By criminalizing her conduct in this instance, the bawdy house law was overly broad, she claimed, an affront to the principles of fundamental justice, and thus in violation of the Charter.

In 2004 the charges against Hamilton were stayed, so we do not know how the court would have ruled on this argument. Grandma's House closed nonetheless after the charges were laid, thus making it difficult to figure out where street-based sex workers are supposed to work and how they can conduct their work safely, as they do not have the resources to set up an indoor location nor the personal characteristics required for escort service and massage parlour work. As Currie et al's [39] research revealed, many of Downtown Eastside/Strathcona women are drug and/or alcohol dependent, and are homeless or live in rooming houses. The message seems to be that the only way they can get help is if they stop the legal act of prostitution.

The closure of Grandma's House forced the streetbased sex workers who used it to perform sexual activities elsewhere, the most likely place being in cars-the very place they find themselves most vulnerable and in the greatest danger.

\section{The Subcommittee on Solicitation Laws (2006) [2]}

In February 2003 Libby Davies, the MP for Vancouver East, which includes the Downtown Eastside, proposed that the House of Commons appoint a special committee to review prostitution law one more time. In light of the charges laid against Pickton, there was broad support for her plea. The review was referred to a subcommittee of what was then called the Standing Committee on Justice,

\footnotetext{
${ }^{26}$ No charges were laid that year against any of the city-licensed massage and body rub parlours that police well knew were fronts for prostitution.

${ }^{27}$ The Subcommittee was reconvened after general elections in 2005 and, with some opposition from the newly elected Conservative party, again in 2006. When its report in December 2006 it was a subcommittee of the Standing Committee on Justice and Human Rights.
}

Human Rights, Public Safety and Emergency Preparedness. ${ }^{27}$

The Subcommittee was asked "to review the solicitation laws in order to improve the safety of sex-trade workers and communities overall, and to recommend changes that will reduce the exploitation of and violence against sex-trade workers" [2, p. 2]. Members of all four federal political parties (two Liberals, two Conservatives, one New Democrat, and one Bloc Québécois) comprised the Subcommittee.

Like every other body that has examined Canadian prostitution law since the Fraser Committee in 1985, Subcommittee members agreed that:

The status quo is unacceptable. The social and legal framework pertaining to adult prostitution does not effectively prevent and address prostitution or the exploitation and abuse occurring in prostitution, nor does it prevent or address harms to communities. This framework must therefore be reformed or reinforced [2, p. 86].

But the Subcommittee was divided over the two conflicting models of law reform that were proposed during its extensive hearings, which included testimony from over 300 witnesses across Canada. It is worth reviewing the main dimensions of this debate as it represents a microcosm of the controversy that has played out around the world over prostitution law:

a) The "sex work as victimization" or radical feminist prohibitionist perspective: prohibit sex purchase, procuring and other forms of "exploitation".

b) The "sex work as work," prostitutes' rights, liberal feminist perspective: remove all reference to prostitution from criminal law.

1) Radical-feminist abolitionism ${ }^{28}$ (e.g. [1,40-44]) - aka the "Nordic" model of prostitution law ${ }^{29}$-is an argument for prohibiting purchase of sex, procuring, and living on the avails of prostitution of another person with the ultimate goal of eradicating prostitution. Because prostitutes are viewed one-dimensionally as "victims", selling sex would continue to be lawful.

The Nordic model enshrines in law the message that prostitution is unacceptable because:

- The distinction between forced and voluntary prostitution is largely spurious; prostitution is female sexual slavery; all prostitutes are victims of "sex trafficking".

- Prostitution is violence against women.

- Prostitution involves an asymmetrical power arrangement in which the seller is subordinate; for this reason, all prostitution is exploitative.

\footnotetext{
${ }^{28}$ For a description of the "radical" compared to other feminist perspectives on prostitution, see Bromberg [45].

${ }^{29}$ For a description of this legal regime, see International Center for Criminal Law Reform and Criminal Justice Policy [46].
} 
- A woman does not truly "consent" to prostitute, even if she claims that she does; very few women would choose to prostitute if they really had choices.

- Selling sex harms the prostitute psychologically and physically.

- Because it treats women as sex objects, prostitution harms all women.

- It will be difficult if not impossible for women to achieve equality or control their own bodies as long as buying sex and third-party profit from prostitution is tolerated.

- Male prostitution involves wealthy older males exploiting younger powerless males.

- Because the "prostituted woman" is a "victim," profiting from prostitution of other persons and buying sex should both be criminal offences.

2) Liberal/libertarian feminism favours "decriminalization" of prostitution, or maintaining its lawful status in jurisdictions where it is not criminalized. Generic criminal and civil laws would be used to control violence and exploitation in any work, including prostitution, and the nuisances associated with any street commerce, including street prostitution. Organized around a defence of prostitutes' rights, it holds that:

- Forced prostitution should be distinguished from voluntary prostitution and cross-border trafficking should be distinguished from migration. Broadly speaking, "sexual slavery" should be distinguished from "prostitution", which involves varying degrees of "choice".

- A woman's/ man's right to control her/ his body includes the right to prostitute.

- Women cannot achieve equality if they do not control their own bodies, including whether to sell sexual services.

- Regardless of whether money changes hands, adults who consent to engage in sex acts that would be legal apart from the payment involved should not be subject to criminal penalty.

- Violence, pimp exploitation, nuisance, low self-esteem are indirectly caused by or exacerbated by the criminalization and stigmatization of prostitution, not by the act of selling sex as such.

- Commercial sex is not necessarily a patriarchal social relation involving an inherently unequal power arrangement.

- As long as sellers and buyers of sex are criminalized, prostitutes will continue to be stigmatized and put at risk of physical and psychological harm.

- When the prostitute and customer contract a sexual service, prostitution should be treated as a form of work.

Although there is considerable terminological slippage, advocates of legal prostitution sometimes distinguish "decriminalization" and "legalization” (e.g. [7; 47, pp. 517-522]).

"Decriminalization" would remove all reference to "prostitution" from criminal law, and would use generic civil laws to control prostitution rather than specific regulation of prostitution. "Legalization" involves specific licensing of prostitutes and/or prostitution establishments, including state control of brothels and the like, combined with criminal law to control various aspects of prostitution, including its visibility. Prostitute rights organizations like the short-lived ASP (Alliance for the Safety of Prostitutes) in Canada and the almost fifty-year old COYOTE $^{30}$ (Call off Your Old Tired Ethics) in the USA oppose "legalization" on the grounds that a rigid regulatory system could end up being as, or more oppressive than criminalization. Indeed, they view the Nevada system, which allows brothels but not independent self-employed prostitution, as a form of "state pimping.,"31

After hearing lengthy submissions from advocates of both camps, the majority report by the Liberal, Bloc Québécois and New Democrat Party members accepted the distinction between forced and voluntary prostitution, and agreed that prostitution between consenting adults should not be subject to criminal penalty:

[S]exual activities between consenting adults that do not harm others, whether or not payment is involved, should not be prohibited by the state... [I]t is preferable to concentrate our efforts on combating exploitation and violence in the context of prostitution, rather than criminalizing consenting adults who engage in sexual activities for money... [G]iven that prostitution itself is not criminalized, the legislature ought to decide where and under what circumstances it can occur [2, p. 90].

The majority report favoured a pragmatic approach that would increase services for people wishing to leave prostitution, and stress harm reduction "to address the underlying concerns of poverty and social inequality and to meet the needs of individuals engaged in prostitution with respect to their health and safety" [2, p. 89]. However, the majority report made no substantive recommendations for law reform, thereby failing to meet its primary mandate [48].

The Conservative party's minority report opposed any form of lawful prostitution. It agreed with the prohibitionist claim that prostitution is violence against women, but was not prepared to embrace the radical-feminist proposal to implement the Nordic model of demand-side prohibition which would mean that selling sex continues to be lawful:

\footnotetext{
${ }^{30}$ See http://www.freedomusa.org/coyotela/coyotela.html

${ }^{31}$ Radical feminists would likely regard just about any type of regulatory system as "state pimping."
} 
[T] he Conservatives do not believe it is possible for the state to create isolated conditions in which the consensual provision of sex in exchange for money does not harm others. [A]ny effort by the state to decriminalize prostitution would impoverish all Canadians-and $\mathrm{Ca}$ nadian women in particular-by signalling that the commodification and invasive exploitation of a woman's body is acceptable. [B]ecause of the negative elements it attracts, prostitution is unacceptable in any location-commercial, industrial or residential, including massage parlours and private homes...

The Conservatives therefore... propose a new approach to criminal justice in which the perpetrators of crime would fund, through heavy fines, the rehabilitation and support of the victims they create... As for the prostitutes themselves, the Conservatives recommend a system in which first-time offenders and those forced or coerced into the lifestyle are assisted out of it, and avoid a criminal record. However, those who freely seek to benefit from the "business" of prostitution would be held accountable for the victimization which results from prostitution as a whole. To address the problem of the two-tiered sex trade... law enforcement must deal equally and consistently with all forms of prostitution, whether it be found on the street, in escort services, massage parlours, bawdy houses, or other locations [2, pp. 90-91].

In commenting on the "Difficulty of Finding Consensus" the Subcommittee concluded that, just like much of the testimony it heard, "the divergence between members' views on prostitution is often philosophical." Conservatives saw it as a "form of violence... a form of exploitation in and of itself". Members representing the three other Federal political parties viewed prostitution by consenting adults "as a human rights issue-the right of an adult to use his or her body to provide sexual services in exchange for money and to operate in a safe environment" [1, p. 92].

These same philosophical and ideological issues would be aired again in the most recent Federal body to consider prostitution law reform at the time of writing, the Twelfth Report of the Standing Committee on the Status of Women [9].

\section{7. "Outrage”: The Standing Committee on the Status of Women (2007)}

Pursuant to its mandate under the order that created the Standing Committee on the Status of Women and the motion that it adopted in September 2006, the Committee's twelfth report [9] examined "human trafficking". Given its claim [9, p. 1] that 92\% of all human trafficking involves sexual exploitation, the Standing Committee did not consider trafficking in any other context.

Rather than beginning with an evaluation of evidence, the majority report began by adding a qualification to the United Nations Protocol to Prevent, Suppress and Punish Trafficking in Persons, Especially Women and Children [49], which defines trafficking as:

The recruitment, transportation, transfer, harbouring or receipt of persons, by means of the threat or use of force or other forms of coercion, of abduction, of fraud, of deception, of the abuse of power or of a position of vulnerability or of the giving or receiving of payments or benefits to achieve the consent of a person having control over another person, for the purpose of exploitation.

Not satisfied with this definition, the majority report added the following proviso:

[T] he Committee considers that definition to be weakened by its lack of clarity with respect to what constitutes sexual exploitation. For that reason, the Committee wishes to clarify that prostitution and pornography are forms of sexual exploitation, wherever they occur-on the street, in massage parlours, modelling agencies, etc., or through escort agencies [9, p. 3].

Its report then examines Canada's efforts to combat trafficking, the prevention of trafficking, the protection of victims, and the prosecution of offenders.

The majority report's first four recommendations involve what would be relatively non-controversial issues for both prohibitionists and regulationists, including tackling gender inequality and poverty, and the many problems affecting Canadian aboriginals. It's fifth, sixth and seventh recommendations encourage the Canadian legislature to adopt the Nordic model of prostitution law that criminalizes the purchase of sex and repeals all offences relating to the activities of sex sellers, including being found in a common bawdy-house and communicating. Other recommendations relate to sex tourism, the prohibition of members of the military from buying sex abroad, the age of consent, combating trafficking in the modeling industry, women's migration, strengthening anti-trafficking measures, more research and data gathering, better education of police about trafficking, enhanced victim services and protection of trafficking victims, and various measures to improve the police and court response to sex trafficking.

An examination of the list of witnesses invited to give testimony to the Standing Committee on the Status of Women raises important questions about the responsibility of any such Committee to give a fair hearing to evidence supporting differences of opinion over the issues it studies.

Rather than hearing testimony from representatives of the two general approaches to prostitution law reform that the Subcommittee on Solicitation Laws identifiedi.e. the "prohibitionist" and "regulationist" camps-researchers who presented evidence to the Subcommittee 
that questioned some of the core claims of prohibitionists were not invited to make submissions to the Standing Committee on the Status of Women.

Given the ideological filter that appears to have been employed in the process of selecting witnesses, perhaps it is not surprising that the Status of Women majority report turned its "outrage” over prostitution into a clarion call for Canada to adopt the "Nordic model" of demand-side prohibition, together with a series of policy and educational initiatives to support it. Even so, the minority report of the two Bloc Québécois members drew attention to the paucity of evidence presented to the Committee and expressed concern about the ideology underpinning the majority report:

The report makes value judgments on prostitution and is condescending at times, especially in Recommendation 6 [criminalize sex purchasing]. The Bloc Québécois opposes sexual exploitation and regards prostitution as a form of it. In our opinion however criminalizing the purchasing of sexual services would not solve the problem; on the contrary, this could increase the risk of assault relating to these practices, which are already dangerous enough... By trying to do too much too quickly, the Committee has overlooked some aspects of the issue and we are unable to support the report in its current form [9, p. 58].

Since 1985 when the Special Committee on Pornography and Prostitution [7] called for fundamental reform of prostitution law some 300 sex workers have been murdered or gone missing. In terms of resolving the obvious contradictions and inconsistencies that the Special Committee identified, we are no further ahead. Dissensus prevails. On one side, the majority report of the Standing Committee on Justice and Human Rights report opted for regulation of consenting adult prostitution. On the other, the Conservative party minority report proposed criminalizing both the buying and selling of sex, whiles the majority report of Standing Committee on the Status of Women preferred the Nordic model of demand-side prohibition.

Not one of these committees has proposed that we keep the current system of "unacceptable" law, and yet the status quo prevails. Meanwhile, women involved in street-level prostitution continue to be murdered and disappear.

Faced with this deadly inertia, two groups of sex workers have turned to the courts for relief, arguing that Canada's prostitution laws violate several of their constitutionally guaranteed rights, especially their right to "security of the person". By turning to the courts they can at least force an evaluation of the evidence being offered to support the current Criminal Code prohibitions.

To understand the Charter arguments currently before the courts, they need to be placed in the context of previous Supreme Court of Canada decisions. To understand these, we turn next to the mechanism enabling judicial review of legislative decisions.

\section{Prostitution Law on Trial}

The Canadian Charter of Rights and Freedoms comprises Part 1 of the Constitution Act (1982), the legislation which formally made Canada a constitutional democracy. Its Constitution specifically allows for judicial review of legislative decisions. ${ }^{32}$ If the Court concludes that a law does limit a protected right, it then has to determine whether that limit is "demonstrably justified in a free and democratic society" (Charter Section 1). To make this determination, the court applies the test laid out in R. v. Oakes ([1986] 1 S.C.R. 103).

The "Oakes test" poses two primary questions:

a) Is the legislative objective of the impugned law of sufficient importance to warrant overriding a constitutionally protected right? The legislative objective must be "pressing and substantial” before it can be characterized as sufficiently important to justify restricting a right.

b) Does the party seeking to invoke Section 1 show that the means chosen are reasonable and demonstrably justified in a free and democratic society? This second question involves a three part "proportionality test" that allows the court to balance the interests of society with those of individuals and groups:

(1) The measures adopted must be rationally connected to the achievement of the objective in question; they must not be arbitrary, unfair or based on irrational considerations.

(2) The means chosen, even if rationally connected to the objective, must impair as little as possible the right and freedom in question.

(3) There must be a proportionality between the effects of the measures responsible for limiting the Charter right or freedom, and the objective which has been identified as being pressing and substantial.

In 1990 and 1992 the Supreme Court of Canada agreed that the communicating and living on the avails law do limit certain Charter rights, but as we shall see next, the Court ruled that the limitations of these rights are "demonstrably justified”.

\footnotetext{
${ }^{32}$ Constitution Act Section 52(1) says. "The Constitution of Canada is the supreme law of Canada, and any law that is inconsistent with the provisions of the Constitution is, to the extent of the inconsistency, of no force or effect."
} 


\section{The Reference Case (1990), R. v. Skinner (1990) and R. v. Downey (1992)}

The first time questions about the constitutional integrity of prostitution law reached the Supreme Court of Canada was in 1990. The case exemplifies the test that courts must employ once they have decided that a law limits a constitutional right, as it did in this instance.

Because of the uncertainty created by a series of lower court decisions, the Province of Manitoba petitioned the Supreme Court to rule on whether the communicating and bawdy house laws violate Charter Section 2(b), which guarantees "fundamental freedoms" such as "freedom of expression" and Section 7, which guarantees "life, liberty and security of the person" and the right "not to be deprived thereof except in accordance with the principles of fundamental justice?”

In determining if a law complies with principles of fundamental justice, the Court has to determine whether it is "unduly broad" or "impermissibly vague". Also the Court was asked to determine whether Section 7 protects "economic rights", in this case a prostitute's right to earn a living.

In its 4:3 decision the majority on the Supreme Court of Canada held that, while the communicating law does infringe freedom of expression, the elimination of the nuisances that street prostitution creates is a governmental objective of sufficient importance to justify that limit (Reference re ss. 193 and 195.1(1)(c), 1990). ${ }^{33}$ The dissenting opinion reasoned that the legislative response of potential imprisonment for a combination of two lawful actions-prostitution and communicating-is much too drastic.

The Supreme Court agreed with the lower courts that the bawdy house laws do not violate the Charter.

In a second case $(R v$. Skinner, 1990) the Supreme Court was asked to rule on whether the communicating law violates Section 2(d) of the Charter-"Freedom of Association"-as well as Section 2(b). The Court upheld the precedent it had set in the reference case regarding 2(b) and ruled that the communicating law did not violate 2(d). It reasoned that communicating for the purpose of buying or selling a sexual act:

$[I]$ s expressive conduct and not conduct of an associational nature. The [communicating law] does not directly proscribe an agreement between two individuals for the exchange of sex for money, nor sexual relations between consenting individuals. The mere fact that an impugned legislative provision limits the possibility of commercial activities or agreements is not sufficient to show a prima facie interference with s.2(d).

\footnotetext{
${ }^{33}$ In 1989 a reorganization of the Criminal Code resulted in these sections being renumbered. As of 1989, s. 193 became s.210 and s. 195.1 became s.213.
}

One of the most important aspects of the Supreme Court's decision in both these cases is that Justice Canada's evaluation - which concluded that the communicating law failed to reduce street prostitution in Toronto and Vancouver, the two cities experiencing the most extensive street prostitution problems [27]—was not entered into evidence. Reflecting on this omission, the Federal-Provincial-Territorial Working Group argued that:

Had the research results been available prior to the Supreme Court decision, the question of whether s.213 [the communicating law] is a justifiable infringement on freedom of expression might have been considered differently [36, p. 7].

In 1992 a man charged for "living on the avails of prostitution" challenged the constitutional validity of the "reverse onus" clause of that law; if a person is habitually in the company of prostitutes the onus switches to that person to prove that he/she was not living on the avails of prostitution of another person.

In another four to three decision, the Supreme Court upheld the law. The majority argued that, while the living on the avails law does infringe Section 11(d) of the Charter - the right to be "presumed innocent until proven guilty according to law"-it is a demonstrably justifiable limit of the right, because by "curbing the exploitive activity of pimps" it is "attempting to deal with a cruel and pervasive social evil". ${ }^{34}$ The court argued that reverse onus clause is proportional given that:

Evidence of pimps living on the avails is difficult, if not impossible, to obtain without the cooperation of the prostitutes, who are often unwilling to testify for fear of violence against them by their pimps... Parliament has chosen a reasonable and sensitive position. To eliminate the presumption completely would reward the accused for the intimidation of vulnerable witnesses in a situation where such intimidation is widespread (R. v. Downey, 1992).

However, the dissenting judges argued that the living on the avails law cast too wide a net:

The section catches people who have legitimate nonparasitic living arrangements with prostitutes... Spouses, lovers, friends, children, parents or room-mates may live with or be habitually in the company of a prostitute, which is not a criminal offence, without living on the avails of prostitution. Any presumption which has the potential to catch such a wide variety of innocent people in its wake can only be said to be arbitrary, unfair and based on irrational considerations. (R. v. Downey, 1992)

Much has changed since these three Supreme Court of Canada decisions, not the least because of the conviction

\footnotetext{
${ }^{34}$ The decision cited the Committee on Sexual Offences Against Children and Youth [6] and the Special Committee on Pornography and Prostitution [7] as providing evidence of this "evil.”
} 
of serial killer Robert Pickton, who may have murdered as many as 49 street-involved women from Vancouver's Downtown Eastside, and because of the much more extensive research that is available about the effects of the enforcement of various prostitution laws. These changes are being brought into sharp relief by the Charter challenges now before the Ontario and BC courts.

\section{Sex Workers Fight for Their Constitutional Rights}

Two groups of former and current sex workers-one in Ontario (Bedford v. Canada), the other in British Columbia (Downtown Eastside Sex Workers United against Violence Society and Sheryl Kiselbach v. Canada)-are currently before the courts challenging various Criminal Code sections relating to prostitution.

The Ontario Charter challenge involves three women who have more than forty years of sex work experience among them. One of the women has already been convicted of keeping a common bawdy house, and all three are concerned that if they continue to work indoors, or resume indoor work, they will be subject to criminal prosecution for violating the bawdy house laws. One of the women is concerned that her partner may be prosecuted for living on the avails of prostitution simply because he lives with her.

The essence of their Charter challenge is that, although it is lawful to work as a prostitute, the bawdy house and living on the avails prohibitions (Criminal Code sections 210 and s.212.(1)(j), respectively) prevent prostitutes from being able to work in a relatively safe and secure environment. The bawdy house prohibition denies the sex seller a safe place for pursuing the lawful act of prostitution. The living on the avails provision prevents the sex seller from hiring the services of third parties to help create a protective work environment. Together with the communicating law, which also violates Section 2(b) of the Charter-freedom of expression - the bawdy house and living on the avails provisions compromise the prostitute's Charter Section 7 right to "life, liberty and security of the person".

In British Columbia the Downtown Eastside Sex Workers United against Violence Society (SWUAV) and a former sex worker also are challenging the constitutional validity of several prostitution laws (Downtown Eastside Sex Workers United against Violence Society and Sheryl Kiselbach v. Canada, 2008). SWUAV comprises street-involved women from Vancouver's Down-

\footnotetext{
${ }^{35}$ Including: a) physical, sexual and emotional violence; b) further discrimination and social alienation; c) reduced ability to access social and medical services; d) eviction from housing; e) attraction of attention from child protection services; and e) more difficult relations with police.
}

town Eastside who, their lawyers argue, do not have the ability individually to commence such an action in their own names, and would be put at risk in a variety of ways $^{35}$ if they identified themselves. They live in poverty, many are Aboriginal, they all have experienced violence in the course of their work, and they have various physical and mental health challenges and disabilities, including substance addiction.

The SWUAV case goes further than its counterpart in Ontario by challenging the constitutional validity of the procuring laws (ss.212, except for subsections (g) and $(\mathrm{i})^{36}$ ) as well as the bawdy house (ss.210, 211, 212.(c)) and communicating (s.213) laws. Also, it adds two constitutional arguments to those advanced in Bedford $v$ Canada (2010).

First, SWUAV argues that the impugned laws violate Charter Section 2(d)- “freedom of association"-by preventing prostitutes from working together, referring clients to other workers, sharing revenue, and maintaining business premises together.

Second, SWUAV argues that the impugned laws violate Charter Section 15, which guarantees "equality before and under law and equal protection and benefit of law without discrimination and, in particular without discrimination based on race, national or ethnic origin, colour, religion, sex, age or mental or physical disability."

SWUAV argues that sex workers as a group are disadvantaged and stigmatized Women, transgendered persons and gay men are over-represented among sex workers, as are aboriginals, people living in poverty, and people with substance addictions. The laws and their enforcement discriminate against street-level sex workers in a variety of ways by, for example, having diversion programs for clients but not sex workers, and by treating street and indoor workers differently. They discriminate against all sex workers by treating them differently from people who have consensual sex without exchange of money, and by treating sex workers differently from other persons who perform other personal services for pay. In summarizing the effects of this discrimination, the Statement of Claim argues:

The adverse effects of the Prostitution Laws on sex workers are wide-ranging, including a heightened risk of violence in the course of their occupation, the exacerbation of pre-existing disadvantage, the imposition of stigma and stereotyping in relation to their occupation, imposition of barriers to accessing services and exiting sex work, and barriers to accessing the protections, rights,

\footnotetext{
${ }^{36} \mathrm{~s} .212 .(1)(\mathrm{g})$ prohibits procuring a person to enter or leave Canada for the purpose of prostitution, and (i) prohibits administering an intoxicant to a person in order to enable anyone to have illicit sexual intercourse with that person.
} 
and entitlements pursuant to workplace, labour and health and safety regulations...

Those regulations include the Employment Standards Act (R.S.B.C., 1996 c. 113), the Worker's Compensation Act (R.S.B.C., 1996), the Labour Relations Code (R.S.B.C., 1996 c. 224), the Human Rights Code (R.S.B.C., 1996 c. 210), the Canadian Human Rights Act (R.S. 1985, c H-6) and the Employment Insurance Act (R.S.C. 1996, c.23) (for further discussion see Pivot Legal Society, 2006).

In December 2008 SWUAV's case hit a speed bump when the court ruled that neither SWUAV nor a former sex worker have either a "private" or "public interest standing" that would enable them to bring their Charter arguments before the court.

Private interest standing occurs when a person has interests that are directly affected by a law, as would be the case if a person had been charged under the impugned Criminal Code prostitution laws. However, SWUAV's is a civil case and does not involve persons who are currently charged under any of those laws.

Public interest standing is granted when a party who has a direct interest in a particular piece of legislation or a genuine interest in its constitutional validity raises a serious issue about its validity and has no other effective way of bringing that issue to court.

The chambers judge ruled that none of the parties had a private interest standing. Further, he ruled that although they clearly have a direct and genuine interest in the validity of the impugned laws, there would be other ways for the case to come before the court, either in the process of a criminal prosecution or if a current prostitute launched a civil suit seeking declaratory relief, as had already happened in Bedford $v$ Canada.

SWUAV appealed the decision to the Court of Appeal for British Columbia, arguing along with several intervenors ${ }^{37}$ that the decision denying standing did not take into sufficient consideration the nature of the lives of the Downtown Eastside women in question. Nor did it take into consideration the "systemic" and "comprehensive" nature of SWUAV's constitutional challenge, which raises questions about the combined effect of the impugned laws. ${ }^{38}$ The Court of Appeal agreed (Downtown Eastside Sex Workers United against Violence Society and Sheryl Kiselbach v. Canada, 2010). In a majority decision it ruled that there is no other way that a woman from this highly marginalized group could be reasonably expected to bring serious questions about the validity of prostitution laws before the court, and noted that Bedford

\footnotetext{
${ }^{37}$ The British Columbia Civil Liberties Association, the Trial Lawyers Association of BC and the West Coast Women's Legal Education and Action Fund.

${ }^{38}$ It would be highly unlikely in a criminal proceeding that a person would be charged with all three of the impugned sections, in which case they may not be able to raise the same kind of challenge.
}

$v$ Canada would be binding in British Columbia only if it were to be upheld by the Supreme Court of Canada. Also SWUAV is raising constitutional issues that are not addressed in Bedford.

The Crown has appealed the Court of Appeal decision to the Supreme Court of Canada, which will hear the case this year (2011).

Although it will have ended up derailing SWUAV's constitutional challenge for at least three years, the matter of standing is crucial when it comes to the principle of equal access to law and the difficulty marginalized groups have accessing justice-especially when the marginalized citizens in question allege that the impugned laws deny them equality under the law.

While observers were waiting for the outcome of SWUAV's appeal on the matter of standing, the Ontario Superior Court delivered its judgment in Bedford.

\section{Bedford v Canada: The Ontario Superior Court of Justice Decision}

The first line of the Crown's defence of the constitutional integrity of Canada's prostitution laws was to argue that the Applicants failed to demonstrate any basis in evidence or law to warrant reconsidering the issues dealt with in the 1990 Reference case.

If the court disagreed with this assessment, and proceeded to hear the specific constitutional arguments being advanced, the Crown argued that Applicants did not meet the evidentiary burden to prove that the impugned laws violate the Charter. The Crown alleged that the Applicants' s.7 argument is based on the assertion that there is a constitutional right to engage in prostitution ${ }^{39}$ and, further, that the Charter does not mandate Parliament to design a legal regime that would allow the Applicants to engage in prostitution with fewer hindrances.

In justifying the impugned laws, the Crown relied primarily on the radical-feminist argument that the social science evidence in Canada and internationally demonstrates that prostitution is inherently dangerous for the individuals involved. It is not the law that causes these harms; prostitution entails significant harm to society regardless of the legal regime in which it occurs. The Crown claimed that prostitution exacerbates other harms, including drug addiction, violence, trafficking and involvement of organized crime. Given these harms, even if the impugned laws do violate any Charter right, the violation is demonstrably justified as a reasonable limit under Section 1.

The two intervenors in Bedford-The Attorney General of Ontario (Ontario) and a religious coalition in-

\footnotetext{
${ }^{39}$ The court clarified that its decision does not address this question (paragraph 25), but then the Applicants did not claim that there is such a constitutional right.
} 
cluding The Christian Legal Fellowship, REAL Women of Canada, and the Catholic Civil Rights League (CLF)similarly sought to defend Canada's prostitution laws on the grounds that prostitution is inherently harmful. Ontario argued that the physical and psychological harms of prostitution arise not from the Criminal Code, but from the inherent inequality that characterizes the prostitutecustomer relationship. The impugned provisions operate to limit the negative effects of prostitution on both the prostitute and the public by curtailing commercialized and institutionalized prostitution, and by prohibiting public prostitution. Societal values and human dignity must be taken into consideration when interpreting the legislative objectives of the impugned provisions.

Adding to this argument, CLF asserted that the laws prohibiting various aspects of prostitution reflect a core Canadian value rooted in interfaith morality and the Charter; prostitution offends the conscience of ordinary Canadians, is immoral, and should be stigmatized. CLF lamented that striking the laws down would send the message that prostitution is a legitimate way for Canadians to make a living.

\section{Research on Trial}

The Applicants and Crown called dozens of witnesses to testify, including police officers, social service providers, sex workers, resident group representatives, a politician, a journalist, and eighteen expert witnesses on prostitution research and research methodology.

The Crown's choice of expert witnesses reveals the ideological premises of its case. The Crown's research experts included three well-known international advocates of radical-feminist demand-side prohibition: Janice Raymond, Melissa Farley and Mary Sullivan. Of these three only Melissa Farley had conducted any research in Canada, a study of street prostitution ${ }^{40}$ in Vancouver [50]. The Crown called only one other witness who has conducted research on prostitution in Canada, including a study of street sex workers [51] and another of men who participated in British Columbia's “john school” [52]. The Crown also called Ottawa sociology Professor Richard Poulin, whose research concerns trafficking and sexual exploitation of children internationally (e.g. [53]). The Applicants called eleven expert witnesses, seven of whom had conducted numerous studies of prostitution and/or prostitution law in Canada. ${ }^{41}$

The case pitted the Crown's claim that prostitution is inherently dangerous and harmful no matter where it

\footnotetext{
${ }^{40}$ The title of the article is "Prostitution in Vancouver" but its authors acknowledge that they did not manage to contact any indoor sex workers.

${ }^{41}$ Cecilia Benoit, Augustine Brannigan, Deborah Brock, John Lowman, Gayle MacDonald, Eleanor Maticka-Tyndale, Frances Shaver.
}

occurs against the Applicant's claim that the laws expose prostitutes to danger by preventing them from taking various kinds of relatively simple safety measures. Consequently, although the Court made it clear that its role was not to decide which model of prostitution law is best, in the process of evaluating the merits of the particular Charter challenge arguments set out by the Applicants it had to evaluate many of the evidentiary claims that are advanced for and against prostitution prohibition. In this sense, research itself was very much on trial because, as the Crown's factum acknowledged, "Much of the argument in this case turns on disputes over what conclusions can be drawn from the voluminous social science evidence - particularly in respect to causality [54, p. 5]”.

\section{Synopsis of the Decision}

The court agreed that the situation in Canada has substantially changed since the Reference case, in which case the legal principle of stare decisis ${ }^{42}$ could be set aside. New legal arguments were being presented along with new evidence, including the government's evaluation of the communicating law [22-27], twenty years more research about violence, and the experience of the serial murder and disappearance of dozens of streetconnected women from Vancouver's Downtown Eastside. Indeed, the government's own research suggested that there is a need to revisit the 1990 Reference decision (paragraphs 69-73 ${ }^{43}$ ).

When it came to the risk of violence against prostitutes, the principle issue at stake, the court concluded:

The evidence $e^{44}$ led on this application demonstrates on a balance of probabilities that the risk of violence towards prostitutes can be reduced, although not necessarily eliminated. The two factors that appear to affect the level of violence against prostitutes are location or venue of work and individual working conditions. With respect to venue, working indoors is generally safer than working on the streets. Working independently from a fixed location (in-call) appears to be the safest way for a prostitute to work in Canada. That said, working conditions can vary indoors, affecting the level of safety (paragraph 300).

After weighing the evidence the court found that:

1) Prostitutes, particularly those who work on the street, are at a high risk of being the victims of physical violence.

\footnotetext{
${ }^{42}$ The doctrine of precedent: a court must follow the decisions made by previous courts in the same province concerning same-fact evidence or legal principle; lower courts are bound by the decisions of higher courts in the same province. All Canadian courts are bound by decisions of the Supreme Court of Canada.

${ }^{43}$ The citations in this section are all to Bedford v Canada, 2010.

${ }^{44}$ The 25,000 pages of evidence including transcripts of cross examinations is posted at http://mypage.uniserve.ca/ lowman/
} 
2) The risk that a prostitute will experience violence can be reduced in the following ways:

a. Working indoors is generally safer than working on the streets;

b. Working in close proximity to others, including paid security staff, can increase safety;

c. Taking the time to screen clients for intoxication or propensity to violence can increase safety;

d. Having a regular clientele can increase safety;

$e$. When a prostitute's client is aware that the sexual acts will occur in a location that is pre-determined, known to others, or monitored in some way, safety can be increased;

$f$. The use of drivers, receptionists and bodyguards can increase safety; and

g. Indoor safeguards including closed-circuit television monitoring, call buttons, audio room monitoring; financial negotiations done in advance can increase safety.

3) The bawdy-house provisions can place prostitutes in danger by preventing them from working in-call in a regular indoor location and gaining the safety benefits of proximity to others, security staff, closedcircuit television and other monitoring.

4) The living on the avails of prostitution provision can make prostitutes more susceptible to violence by preventing them from legally hiring bodyguards or drivers while working. Without these supports, prostitutes may proceed to unknown locations and be left alone with clients who have the benefit of complete anonymity with no one nearby to hear and interrupt a violent act, and no one but the prostitute able to identify the aggressor.

5) The communicating provision can increase the vulnerability of street prostitutes by forcing them to forego screening customers at an early and crucial stage of the transaction (paragraph 421).

The presiding judge concluded that the three impugned provisions prevent prostitutes from taking precautions, some rudimentary, that can reduce the risk of violence towards them. Consequently, "Prostitutes are faced with deciding between their liberty and their security of the person. Thus while it is ultimately the client ${ }^{45}$ who inflicts violence upon a prostitute, in my view the law plays a sufficient contributory role in preventing a prostitute from taking steps that could reduce the risk of such violence" (paragraph 362).

Having found that the laws violate certain Charter rights, the court then employed the Oakes test to determine whether the legislative objective of each law is of

\footnotetext{
${ }^{45}$ With these comments the court failed to recognize that an unknown proportion of much of the violence is committed by men posing as clients, as they did not intend to purchase a sexual service.
}

sufficient importance to warrant overriding a constitutionally protected right. To establish whether the laws are reasonable and demonstrably justified in a free and democratic society, the court had to consider whether they are rationally connected to the achievement of their objective and consistent with the principles of fundamental justice, and whether they impair a prostitute's rights as little as possible.

The Applicants argued that the impugned provisions are not in accordance with the principles of fundamental justice because they arbitrarily deprive individuals of their protected rights, are overly broad to the extent that they capture behavior that lies beyond their stated purpose, the harmful effects are grossly disproportionate to their benefits, and they are not consistent with the rule of law.

The court agreed on most counts.

While the court found that the legislative objective of the living on the avails offence is to prevent exploitation of prostitutes, ironically "it may serve to increase the vulnerability of those it is intended to protect" (paragraph 379) and is "overly broad" because it captures several non-exploitative arrangements (paragraph 402).

Although the court did not find that the bawdy-house provisions are themselves arbitrary, "their interplay with the other impugned provisions renders them so" (paragraph 385). Because they assign criminal liability to those direct participants of bawdy house prostitution who do not contribute to the harms Parliament seeks to prevent, "the bawdy-house provisions are overly broad as they restrict the liberty and security of the person more than is necessary to accomplish their goals" (paragraph 401).

The primary purpose of bawdy house laws is to prevent nuisance, a legitimate state objective. However, this objective has to be balanced against its effect on prostitute safety. Given that complaints about bawdy-houses are relatively rare (paragraph 427) the court held that the effects of the bawdy-house provisions - which prevent prostitutes from working in a relatively safe indoor environment-are grossly disproportional to their purpose (paragraph 428).

The prohibition of living on the avails targets the financial exploitation of prostitutes, another legitimate state interest. However, this objective has to be balanced against the effect of that law in preventing prostitutes from legally hiring bodyguards, drivers, or other security staff. In this respect, the court concluded that the law presents prostitutes with a "perverse choice": they can safeguard their security, but only at the expense of another's liberty. These effects place prostitutes at greater risk of harm and may make it more likely that a prostitute will be exploited (paragraph 429). 
The communicating law fulfills a legitimate state purpose by targeting the general nuisance created by street prostitution, including noise and street congestion. However, these objectives must be balanced against the fact that the provision forces prostitutes to forego screening clients, which the court found to be an essential tool to enhance their safety (paragraph 432):

... one effect of the communicating provision (as well as the bawdy-house provisions) is to endanger prostitutes while providing little benefit to communities. In fact, by putting prostitutes at greater risk of violence, these sections have the effect of putting the larger society at risk on matters of public health and safety. The harm suffered by prostitutes carries with it a great cost to families, law enforcement, and communities and impacts upon the well-being of the larger society (paragraph 434).

Although the communicating law is rationally connected to its objective, it prohibits all communicative activity for the purpose of engaging in prostitution or of obtaining the sexual services of a prostitute, not merely those communications that tend to contribute to social nuisance. The court concluded that the evidence tends to demonstrate that some of the communication being curtailed is capable of reducing the risk of harm to streetbased prostitutes who are statistically much more likely than the general population to be victims of violence. Curtailing these communications "constitutes a more serious impairment of the individual's freedom than the avowed legislative objective would warrant". On this basis alone, the court found that the communicating provision does not "minimally impair" the expressive rights of the Applicants and therefore cannot be upheld as a "reasonable limit" under s.1 (paragraph 472).

These effects are all the more problematic given that the communicating law does not appear to effectively curtail the social nuisance associated with street prostitution. While the communicating law may allow the police to direct prostitutes to social services or capture pimps on occasion, the government evaluation [27] suggests that its salutary effects in combating the social nuisance associated with street prostitution are minimal (paragraph 499).

After weighing the importance of its objective and salutary effects against its deleterious effects, the court found that the communicating provision creates an unreasonable limit on the prostitute's freedom of expression (paragraph 489). In the final balancing, the court concluded that, "in pursuing its legislative objective, the communicating provision so severely trenches upon the rights of prostitutes that its pressing and substantial purpose is outweighed by the resulting infringement of rights" (paragraph 504).

The court concluded that the Applicants had proved on a balance of probabilities that the impugned provisions infringe their Charter rights, their effects are not proportionate to their objectives, and they do not minimally impair the Applicants' rights to liberty and security of the person.

Because the Crown was not able to demonstrate that any of the infringements are justified under s.1 of the Charter, the court declared that the bawdy-house provisions, the living on the avails provision, and the communicating provision (ss.210, 212.(1)(j), and 213.(1)(c) of the Criminal Code respectively) violate s.7 of the Charter and are, therefore, unconstitutional (paragraph 506). The court further concluded that the communicating provision violates s.2(b) of the Charter, and also could not be saved by s.1 (paragraph 507).

The Crown immediately appealed the decision, which is now before the Appeal Court of Ontario. At the time of writing, the Ontario Superior Court's decision has been stayed pending the outcome of the appeal, which will be heard in 2011.

\section{Conclusions}

It will take several years for the Ontario and British Columbia Charter challenges to be concluded, as whatever decisions the lower courts make are likely to be appealed by the losing party all the way to the Supreme Court of Canada. The Supreme Court does not necessarily have to hear an appeal. However, because provincial appeal court decisions are only binding in the province in which they occur, if the Ontario and British Columbia appeal courts reach conflicting conclusions about the constitutional status of the prostitution laws-i.e. should one uphold them and the other strike them down - the Supreme Court of Canada would presumably hear the case in order to resolve the contradictory jurisprudence at the provincial level. Given the serious nature of the issues at stake, the Supreme Court of Canada may well hear these cases regardless.

If the Supreme Court ultimately upholds the Ontario Superior Court's decision to strike down the laws, the Canadian legislature will be forced to rewrite its prostitution laws. Given the rationale underlying the decision, it is difficult to see how tinkering with the wording of these laws will resolve the Charter violations the court identified. At that point the legislature will either have to opt for direct prohibition of the sale of sex, the purchase of sex, or both, or it will have to pave the way for a system of regulation that identifies where and under what circumstances prostitution can occur.

Either way, one can only hope that the decision will bring an end to the deadly inertia that has beset Canadian prostitution law reform since 1985 when the Special Committee on Pornography and Prostitution called for 
fundamental reform to resolve the contradictions that beset these "unacceptable" laws.

\section{Acknowledgements}

Thanks to Michael Goodyear, Ted Palys and Teela Sanders for their comments on earlier drafts of this paper.

\section{REFERENCES}

[1] G. Ekberg, “Abolishing Prostitution: The Swedish Solution. An Interview with Gunilla Ekberg," Rain and Thunder: A Radical Feminist Journal of Discussion and Activism, Vol. 41, 2008.

http://action.web.ca/home/catw/attach/R\%26T_Interview _with_Gunilla_Ekberg.pdf

[2] Subcommittee on Solicitation Laws of the Standing Committee on Justice and Human Rights, "The Challenge of Change: A Study of Canada's Criminal Prostitution,” Government of Canada, Ottawa, 2006. http://www2.parl.gc.ca/content/hoc/Committee/391/JUST /Reports/RP2599932/justrp06/sslrrp06-e.pdf

[3] A. Jolin, "On the Backs of Working Prostitutes: Feminist Theory and Prostitution Policy," Crime and Delinquency, Vol. 40, No. 1, 1994, pp. 69-83. doi:10.1177/0011128794040001005

[4] J. S. Russell, "The Offence of Keeping a Common Bawdy House in Canadian Criminal Law," Ottawa Law Review, Vol. 14, No. 2, 1982, pp. 270-313.

[5] J. McLaren, "Chasing the Social Evil: Moral Fervour and the Evolution of Canada's Laws, 1867-1917,” Canadian Journal of Law and Society, Vol. 1, 1986, pp. 125-165.

[6] Committee on Sexual Offences against Children and Youth, "Sexual Offences against Children," Department of Supply and Services, Ottawa, 1984.

[7] Special Committee on Pornography and Prostitution (the Fraser Committee), "Pornography and Prostitution: In Canada,” Department of Supply and Services, Ottawa, 1985.

[8] Federal-Provincial-Territorial Working Group on Prostitution (Working Group 1998), "Report and Recommendations in Respect of Legislation, Policy and Practices Concerning Prostitution-Related Activities,” Department of Justice, Ottawa, 1998.

[9] Standing Committee on the Status of Women, "Turning Outrage into Action to Address Trafficking for the Purpose of Sexual Exploitation in Canada: Report of the Standing Committee on the Status of Women," Communication Canada, Ottawa, 2007, p. 3.

http://cmte.parl.gc.ca/content/hoc/committee/391/fewo/re ports/rp2738918/feworp12/feworp12-e.pdf

[10] J. Gray, "Red Lights on the Prairies,” Signet, New York, 1971.

[11] D. Nilsen, "The 'Social Evil': Prostitution in Vancouver, 1900-1920,” In: B. Latham and C. Kess, Eds., In Her Own Right: Selected Essays on Women's History in B.C., Camosun College, Victoria, 1980, pp. 205-228.
[12] N. Larsen, “Canadian Prostitution Control between 1914 and 1970: An Exercise in Chauvinist Reasoning," Canadian Journal of Law and Society, Vol. 7, No. 2, 1992, pp. 137-156.

[13] L. Rotenberg, “The Wayward Worker: Toronto's Prostitute at the Turn of the Century," In: J. Acton, P. Goldsmith and B. Shepherd, Eds., Women at Work, Ontario 1850-1930, Canadian Women's Educational Press, Toronto, 1974.

[14] Vancouver Sun, "Trade Brisk in Call Girls: Sun Reveals Taxis Are Key to Sale of Sex,” Vancouver Sun, 12 January 1959, p. 1.

[15] M. Layton, "Report on Prostitution in Vancouver: Official and Unofficial Reports," Unpublished Report to the British Columbia Police Commission, 1975.

[16] R. Prus and S. Irini, "Hookers, Rounders and Desk Clerks,” Gage Publishing, Toronto, 1980.

[17] D. R. Brock, "Making Work, Making Trouble: Prostitution as a Social Problem," University of Toronto Press, Toronto, 1998.

[18] J. Lowman, "Street Prostitution in Vancouver: Notes on the Genesis of a Social Problem," Canadian Journal of Criminology, Vol. 28, No. 1, 1986, pp. 1-16.

[19] D. L. Winterton, "The Dilemma of Our Prostitution Laws," Canadian Police Chief, Vol. 69, No. 2, 1980.

[20] K. Doyle, “The Sexual Debate,” Maclean's, 15 April 1985, p. 1.

[21] Standing Committee on Justice and Legal Affairs, "Report to the House," Solicitation for the Purposes of Prostitution, 1983.

[22] J. Lowman, "Street Prostitution: Assessing the Impact of the Law, Vancouver," Department of Justice, Ottawa, 1989.

[23] A. Brannigan, L. Knafla and C. Levy, "Street Prostitution: Assessing the Impact of the Law, Calgary, Regina and Winnipeg,” Department of Justice, Ottawa, 1989.

[24] R. Gemme, N. Payment and L. Malenfant, "Street Prostitution: Assessing the Impact of the Law, Montreal,” Department of Justice, Ottawa, 1989.

[25] F. Graves, "Street Prostitution: Assessing the Impact of the Law, Halifax,” Department of Justice, Ottawa, 1989.

[26] S. Moyer and P. J. Carrington, "Street Prostitution: Assessing the Impact of the Law, Toronto," Department of Justice, Ottawa, 1989.

[27] J. Fleischman, "Street Prostitution: Assessing the Impact of the Law, Synthesis Report,” Department of Justice, Ottawa, 1989, pp. 7-8.

[28] J. Lowman, "Submission to the Subcommittee on Solicitation Laws,” 21 February 2005. http://mypage.uniserve.ca/ lowman/

[29] Standing Committee on Justice and the Solicitor General, "Report of the Standing Committee on Justice and the Solicitor General Concerning the Three-Year Review of Section 213 of the Criminal Code," 1990.

[30] A. Brannigan, "Victimization of Prostitutes in Calgary 
and Winnipeg,” Technical Report No. TR1996-15e, Department of Justice, Ottawa, 1996.

[31] J. Fleischman, "Violence against Street Prostitutes in Halifax,” Technical Report No. TR1996-16e, Department of Justice Canada, Ottawa, 1996.

[32] La boîte à qu’on-se-voir, "Étude sur les violences envers les prostituées à Montréal," Technical Report No. TR1996-17e, Department of Justice Canada, Ottawa, 1996.

[33] J. Lowman and L. Fraser, "Violence against Persons Who Prostitute: The Experience in British Columbia,” Technical Report No. TR1996-14e, Department of Justice Canada, Ottawa, 1996. http://24.85.225.7/lowman_prostitution/HTML/violence/ Violence_Against_Persons_Who_Prostitute.pdf

[34] J. Lowman, "Violence and the Outlaw Status of (Street) Prostitution in Canada," Violence against Women, Vol. 6, No. 9, 2000, pp. 987-1011. doi:10.1177/10778010022182245

[35] The Federal-Provincial-Territorial Task Force on Prostitution, "Dealing With Prostitution in Canada: A Consultation Paper,” Department of Justice, Ottawa, 1995.

[36] C. Skelton, "Is Vancouver's Downtown Eastside Really 'Canada's Poorest Postal Code?'” Vancouver Sun, 10 February 2010.

http://communities.canada.com/vancouversun/blogs/paren ting/archive/2010/02/10/downtown-eastside-poorest-post cal-code.aspx

[37] P. Leidl, "Prosperity and Poverty Make for Uneasy Bedfellows in World's Most Livable City,” Feature Story from the United Nations Population Fund Report State of World Population 2007: Unleashing the Potential of Urban Growth, 2007, http://www.unfpa.org/swp/2007/presskit/index.htm

[38] R. Stall, "Mayor to Propose Skid-Row Reward," The Province, 25 April 1999, p. A16.

[39] S. Currie, N. Laliberte, S. Bird, N. Rosa and S. Sprung, "Assessing the Violence against Street-Involved Women in the Downtown Eastside/Strathcona Community," A study funded by the Ministry of Women's Equality, the Downtown Eastside Youth Activities and Watari, Mimeo, 1995.

[40] K. Barry, "Female Sexual Slavery," New York University Press, New York, 1979.

[41] A. Dworkin, "Prostitution and Male Supremacy," Address Given at the Symposium Entitled "Prostitution: From Academia to Activism," Sponsored by the Michigan Journal of Gender and Law at the University of Michigan Law School, 31 October 1992.

http://www.nostatusquo.com/ACLU/dworkin/MichLawJo urI.html

[42] M. Farley, "Bad for the Body, Bad for the Heart: Prostitution Harms Women Even If Legalized or Decriminal- ized,” Violence against Women, Vol. 10, No. 10, 2004, pp. 1087-1125. doi:10.1177/1077801204268607

[43] J. Raymond, "10 Reasons for Not Legalizing Prostitution,” Coalition against Trafficking in Women International, 2003.

http://action.web.ca/home/catw/attach/Ten\%20Reasons\% 20for\%20Not\%20Legalizing\%20Prostitution.pdf

[44] J. Raymond, "Prostitution on Demand," Violence against Women, Vol. 10, No. 11, 2004, pp. 1156-1186. doi:10.1177/1077801204268609

[45] S. Bromberg, "Feminist Issues in Prostitution,” In: J. E. Elias, L. Bullough, V. Elias and G. Brewer, Eds., Prostitution: On Whores, Hustlers and Johns, Prometheus, New York, 1998, pp. 294-321.

[46] International Center for Criminal Law Reform and Criminal Justice Policy, "An Exploration of Promising Practices in Response to Human Trafficking in Canada," A Report commissioned by the Government of Manitoba on behalf of the Federal/Provincial/Territorial Forum of Senior Officials responsible for Status of Women, 2010. http://www.gov.mb.ca/msw/publications/human_trafficki ng.pdf

[47] F. Shaver, "Prostitution: A Critical Analysis of Three Policy Approaches,” Canadian Public Policy, Vol. 11, No. 3, 1985, pp. 493-503. doi: $10.2307 / 3550504$

[48] Stella and Maggies, "Not up to the Challenge of Change: An Analysis of the Report of the Subcommittee on Solicitation Laws," Canadian HIV/AIDS Legal Network, 2007.

http://www.aidslaw.ca/publications/publicationsdocEN.p hp?ref=665.

[49] United Nations, "Protocol to Prevent, Suppress and Punish Trafficking in Persons, especially Women and Children," Supplementing the United Nations Convention against Transnational and Organized Crime, 2000. http://www.uncjin.org/Documents/Conventions/dcatoc/fi nal_documents_2/convention_\%20traff_eng.pdf

[50] M. Farley, J. Lynne and A. J. Cotton, "Prostitution in Vancouver: Violence and the Colonization of First Nation's Women,” Transcultural Psychiatry, Vol. 42, No. 2, 2005, pp. 242-271. doi:10.1177/1363461505052667

[51] M. A. Kennedy, C. Klein, J. T. K. Bristowe, B. S. Cooper and J. C. Yuille, "Routes of Recruitment: Pimp and Other Pathways into Prostitution,” Journal of Aggression, Maltreatment and Trauma, Vol. 15, No. 2, 2007, pp. 1-19. doi:10.1300/J146v15n02_01

[52] M. A. Kennedy, C. Klein, B. B. Gorzalka and J. C. Yuille, "Attitude Change Following a Diversion Program for Men Who Solicit Sex," Journal of Offender Rehabilitation, Vol. 40, No. 1-2, 2004, pp. 41-60.

[53] R. Poulin, "La Mondialisation des Industries du Sexe," L'f nterligne, Ottawa, 2004.

[54] Attorney General of Canada, "Factum of the Respondent, the Attorney General of Canada,” Bedford v. Canada, 2010 ONSC 4264, 2009. 


\section{Cases Cited}

Reference re ss. 193 and 195.1(1)(c) of the criminal code (Man.) 1 S.C.R. (1990)

Bedford v. Canada, 2010 ONSC 4264

Downtown Eastside Sex Workers United Against Violence Society and Sheryl Kiselbach v. Canada 2008 BCSC 1726

Downtown Eastside Sex Workers United Against Violence Society v. Canada (Attorney General) 2010 BCCA 439
R. v. Blais (2007) Port Coquitlam Provincial Court Registry No. 76644.

R. v. Caine/Malmo-Levine (2003) 1 S.C.R. 571

R. v. Downey, (1992) 1 S.C.R. 21874

R. v. Hutt (1978) 82 D.L.R. (3d) 95

R. v. Oakes (1986) 1 S.C.R. 103

$R$ v. Skinner (1990) 1.S.C.R. 1235

R. v. Whitter, (1981) 2 S.C.R. 606 